\title{
Assessment of Seasonal Variations in Forage Quality in Saanane Island National Park, Mwanza, Tanzania
}

\author{
George M. Sangu ${ }^{1 *}$ and Cuthbert L. Nahonyo ${ }^{2}$ \\ ${ }^{1}$ University of Dar es Salaam, Department of Botany, P. O. Box 35060 Dar es Salaam, \\ Tanzania. E-mail: sangug34@yahoo.com \\ ${ }^{2}$ University of Dar es Salaam, Department of Zoology and Wildlife Conservation, \\ P. O. Box 35064, Dar es Salaam, Tanzania. E-mail: nahonyo@udsm.ac.tz \\ *Corresponding author
}

Received 14 Feb 2021, Revised 9 Dec 2021, Accepted 14 Dec 2021, Published Dec 2021

DOI: $\underline{\text { https://dx.doi.org/10.4314/tjs.v47i5.30 }}$

\begin{abstract}
Seasonal variations in proteins, vitamin $\mathrm{A}$, vitamin $\mathrm{C}$, carbohydrates and minerals $(\mathrm{Ca}, \mathrm{Fe}, \mathrm{Na}$, $\mathrm{K}$ and $\mathrm{P}$ ) for seven most grazed and four most browsed plant species were assessed using laboratory analysis to determine what nutrient resources were available to grazers and browsers inhabiting the Saanane Island. The results indicated great seasonal variations in proteins, vitamin $\mathrm{A}$, vitamin $\mathrm{C}$ and carbohydrates which were statistically significant with $\mathrm{P}<0.01, \mathrm{~F}$ 3.444 at DF 5. Similarly, the minerals ( $\mathrm{Ca}, \mathrm{Fe}, \mathrm{Na}, \mathrm{K}$ and $\mathrm{P}$ ) showed greater seasonal variations with $\mathrm{K}$ and $\mathrm{P}$ being higher during wet season, while $\mathrm{Na}$ and $\mathrm{Fe}$ were higher in dry season. The levels of proteins, vitamins, fibres and minerals were well above daily dietary requirements for grazers and browsers. These results suggested that both grazers and browsers were benefiting from seasonal differences in terms of available resources at disposal as animal health is regulated by levels of proteins and vitamins available in grazing and browsing materials.
\end{abstract}

Keywords: Forage Quality, Minerals, Protein Saanane, Seasonality, Vitamin.

\section{Introduction}

The productivity of rangelands is largely dependent on climatic factors (Arzani et al. 2008) and biotic factors (Henkin et al. 2011) that vary tremendously with season in an area within the same ecological zone (Teka et al. 2012). The variations are manifested in terms of biomass production and nutrient allocation within the plants and among the species forming the rangeland. The variations are attributed to seasonal variability and alteration of rangeland ecosystem by climatic conditions, natural disasters, anthropogenic influences and grazing pressure (Teka et al. 2012). Ozone exposure for example can cause increases in foliar injury and reduction in biomass yield, as well as alter resource allocation and nutritive quality (Krupa et al. 2004). Alterations in biomass production and nutrient allocation may directly and indirectly influence performance of wildlife communities and species dependent on forage materials available.

Forage quality and quantity are most important components of the rangeland; as it highlights what nutrients the browsers and grazers are exposed to in a given season. For the grazing and browsing animals to obtain the resources, the diversity of forage and accessibility of the area by grazers/browsers to reach the resource are critical. According to Ganskopp and Bohnert (2001) knowledge of the nutritional quality of rangeland forages is important to sustain satisfactory growth and reproduction of livestock. Little information was known about developmental and seasonal variability in proteins, carbohydrates, minerals and vitamin contents of cereals, 
legumes, grasses and forbs materials that serve as important food resources to grazers and browsers inhabiting the Saanane Island. The variabilities of the nutrients available in forage materials were determined and their seasonal variations assessed. The hypothesis was that grazed and browsed materials growing in wet season should be rich in all minerals, vitamins $\mathrm{A}$ and $\mathrm{C}$, proteins and carbohydrates.

\section{Materials and Methods Study area}

The study site was located about $2 \mathrm{~km}$ southwest from Mwanza city centre, which lies in the Gulf of Lake Victoria at latitude $2^{\circ} 16.5^{\prime}$ and longitude $32^{\circ} 27.5^{\prime}$ (Figure 1 ). Saanane Island constitutes rocky hills covered by shrubs and few trees. Diospyros mespiliformis and Ficus sycamorus trees can be seen on slopes with deep soils. The interlocking rocky hills provide a shading effect resulting into the formation of grassland patches that were sampled for grazed plant species (Katalihwa 1981). The island hosts impala, velvet monkey, wild cat, zebra and rock hyrax.

\section{Sampling}

Sampling was carried for four days in March 2017 for the wet season and repeated in August 2017 for the dry season data. Prior to sampling for each season, a one-day reconnaissance survey was carried out in order to orient and familiarize with the site for data collection, to describe and classify the vegetation in general terms. The description and classification of vegetation adapted the classification described by Greenway (1973), White (1983) and Beentje (1994). This classification combined physiognomic and floristic criterion including the dominant species in the community.

\section{Plant sampling}

Plant samples for grazed materials were collected using systematic random sampling whereby randomly placed transects were established at each of the 5 grassland patches of the Saanane Island (Walker 1970). At each transect, a $1 \times 1$ square meter quadrate was established after every $50 \mathrm{~m}$ making a total of 43 quadrates. Samples were collected in two seasons covering wet and dry seasons as described above. In each quadrate, herbaceous and grass species were identified to species level whenever possible, and those which could not be identified on spot were collected and taken to the herbarium for identification and confirmation of their taxa using Flora of Tropical East Africa book (2002) and mounted reference specimens available in the herbarium at the Department of Botany, University of Dar es Salaam.

Also representatives of the grass species that were found to be most grazed and four most browsed plant species were collected and preserved in absolute alcohol and taken to the plant science laboratory in the Department of Botany, University of Dar es Salaam for mineral, protein, vitamins $\mathrm{A}$ and $\mathrm{C}$, and carbohydrates analysis. 


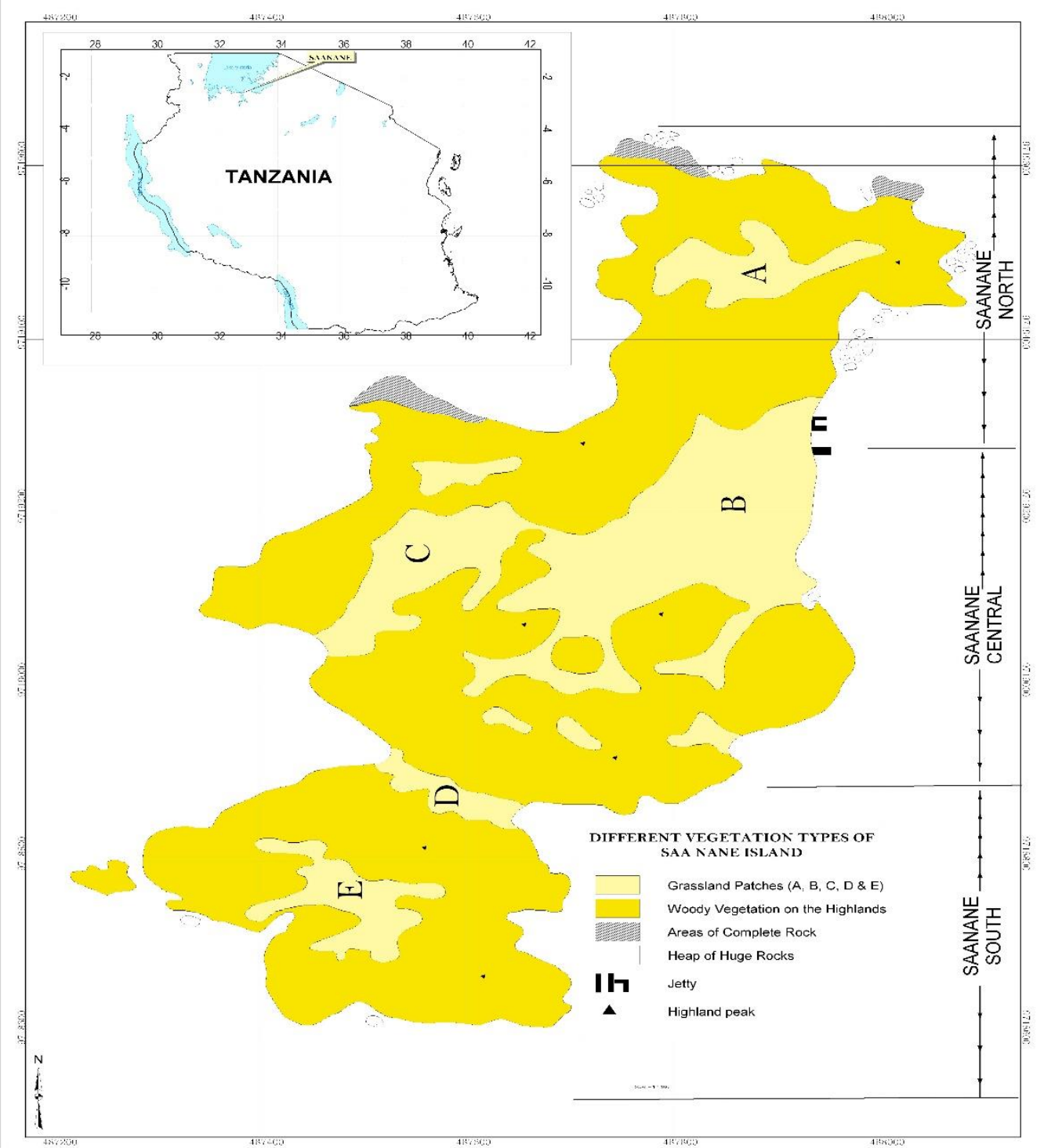

Figure 1: Saanane Island Mwanza, showing vegetation classification and zones (Source Katalihwa 1981).

\section{Nutrient and mineral analyses}

Four samples of the edible parts from each species of the best seven most grazed and four browsed plant species were analysed for crude proteins, crude fibre contents, soluble carbohydrates (sugar), calcium, iron, sodium, potassium, phosphorus and vitamins (A and C) using standard laboratory procedures for nutrient determination. Crude proteins were determined using a macro-Kjeldahl apparatus. The Kjeldahl analysis depends on the measurement of nitrogen $(\mathrm{N})$ in the test material. To convert the measured $\mathrm{N}$ content of the test material to crude protein, a calculation factor of $6.25(\mathrm{~N} \times 6.25)$ is applied. This is based on the fact that all proteins contain about $16 \% \mathrm{~N}(100 / 16=6.25)$ or $16 \mathrm{~g}$ of $\mathrm{N}$ comes from $100 \mathrm{~g}$ proteins, or 1 $\mathrm{g}$ of $\mathrm{N}$ is associated with $100 / 16=6.25 \mathrm{~g}$ of proteins. This process of nitrogen determination involves boiling the dried samples in $36 \mathrm{~N}$ sulfuric acid $\left(\mathrm{H}_{2} \mathrm{SO}_{4}\right)$. This 
will convert nitrogen to ammonium sulfate $\left(\left[\mathrm{NH}_{4}\right]_{2} \mathrm{SO}_{4}\right)$. The mixture is then cooled and neutralized with $12 \mathrm{~N}$ sodium hydroxide $(\mathrm{NaOH})$. This will release ionized ammonium. The sample is then distilled, and the distillate containing the ammonium is titrated with $0.02 \mathrm{~N}$ sulfuric acid. This analysis is accurate and repeatable, and is applicable to ruminant animals that can efficiently utilize all forms of $\mathrm{N}$.

Crude fibre $(\mathrm{CF})$ was analysed according to AOAC (2002). Phosphorus was determined according to the Vanadomolybdophosphoric Acid Method (Shio 1996) using a atomic absorption spectrophotometry (Jenway 6100, UK). The mineral composition (iron, calcium, sodium, and potassium) of the forages were analyzed using atomic absorption spectrophotometry (Zohary 1973).

Plant samples collected were thoroughly washed by distilled water to remove all adhering soil particles. Samples were then oven dried to constant weights at $105{ }^{\circ} \mathrm{C}$. Each dried sample was ground to powder using a wearing blender (Model type A 10 Janke and Kunkel GBH a Co. KG) according to Allen (1989). One gram of each sample was used for analysis. These samples were then digested using $5 \mathrm{ml}$ of 5:1 of concentrated nitric $\left(\mathrm{HNO}_{3}\right)$ and perchloric acid $\left(\mathrm{HClO}_{4}\right)$ mixture according to Allen (1989), then heated in a Kjeldahl vessel at $120{ }^{\circ} \mathrm{C}$ until complete digestion was achieved. After digestion, samples were left to cool to room temperature. Then, samples were prepared for mineral analysis by adding distilled water to $50 \mathrm{ml}$. The initial preparation of samples, digestion and dilution were carried out in the Department of Botany and the analysis of the levels of minerals was done using a Perkin-Elmer 3100 Atomic Absorption Spectrophotometer at the College of Engineering, Department of Chemical and Mining Engineering, University of Dar es Salaam. The percentage recoveries from the analysis of the standard reference materials by the procedures that were used were $80 \% \mathrm{Fe}$, $85 \% \mathrm{Ca}, 90 \% \mathrm{Na}, 83 \% \mathrm{~K}$ and $85 \% \mathrm{P}$.

\section{Data analyses}

All obtained data were tested for normality and homogeneity of variances using Kolmogorov-Smirnov test and Shapiro-Wilk test. All data passed the normality test and were subjected to parametric tests. Two sample t-test was used to compare the differences in $\mathrm{Fe}, \mathrm{Ca}, \mathrm{Na}, \mathrm{K}, \mathrm{P}$, vitamin $\mathrm{A}$, vitamin $\mathrm{C}$, total carbohydrates, crude protein and crude fibres between the two seasons of the grazed materials, while Multiple comparisons test using Single Factor Analysis of Variance at $\mathrm{P}<0.05$ was used to compare nutrient variations among the grazed species and browsed species according to Zar (1999).

\section{Results and Discussion}

\section{Forage quality}

Protein, vitamin $\mathrm{A}$, vitamin $\mathrm{C}$, crude fibres, carbohydrate and mineral ( $\mathrm{Fe}, \mathrm{Ca}, \mathrm{Na}$, $\mathrm{K}, \mathrm{P}$ ) contents of the forage materials were found to vary with species, age of the plants and seasons. Results presented on Table 1 (age of the plant), Tables 2 and 3 (seasons) indicated high protein contents, vitamin $\mathrm{A}$, and vitamin $C$ for samples collected on young species compared to matured species. However, for minerals, a reversed trend was observed, where matured samples had higher mineral contents than those collected from young materials. Wet season forage materials contained much higher proteins, carbohydrates and vitamins than the dry season materials concurring with Teka et al. (2012) who found that the nutritional quality of herbaceous species under arid conditions was influenced by the seasonality of rainfall. Similar results have been reported in herbaceous species in semi-arid areas in Ethiopia by Mahala et al. (2009).

For minerals and fibre contents, the higher values observed as plants mature in dry season (Table 1) are supported by the findings of Teka et al. (2012) study which found that the higher levels are due to the structural constituents (i.e. lignin, cellulose and hemicellulose) of plant materials which usually increase with the stage of maturity of a species. 
Table 1: Contents of protein, vitamins, crude fibre and minerals in young and mature fronds on selected grazed plant species

\begin{tabular}{|c|c|c|c|c|c|c|}
\hline \multicolumn{3}{|l|}{ Species } & $\begin{array}{l}\text { Hyparrhennia } \\
\text { filipendula }\end{array}$ & $\begin{array}{l}\text { Eragrostis } \\
\text { cilianensis }\end{array}$ & $\begin{array}{l}\text { Digitaria } \\
\text { velutina }\end{array}$ & $\begin{array}{l}\text { Total } \\
\text { number of } \\
\text { samples }\end{array}$ \\
\hline \multicolumn{3}{|c|}{ Sample size } & 4 & 4 & 4 & 12 \\
\hline \multirow[t]{2}{*}{ Protein } & \multirow[t]{2}{*}{$\% \mathrm{DM}$} & $\mathrm{Y}$ & 8.7 & 20.2 & 7.6 & \\
\hline & & $\bar{M}$ & 2.1 & 1.2 & 2.2 & \\
\hline \multirow[t]{4}{*}{ Vitamins } & \multirow[t]{2}{*}{$\mathrm{A}(\mathrm{mg} / 100 \mathrm{~g})$} & $\mathrm{Y}$ & 65.7 & 78.2 & 96.3 & \\
\hline & & $\bar{M}$ & 17 & 22 & 34 & \\
\hline & \multirow[t]{2}{*}{$\mathrm{C}(\mathrm{mg} / 100 \mathrm{~g})$} & $\mathrm{Y}$ & 112.5 & 122.2 & 92.3 & \\
\hline & & $\mathrm{M}$ & 26 & 43 & 36 & \\
\hline \multirow[t]{2}{*}{$\mathrm{C} /$ fibre } & \multirow[t]{2}{*}{$\% \mathrm{DM}$} & $\mathrm{Y}$ & 78.6 & 58.7 & 75.6 & \\
\hline & & $\bar{M}$ & 64 & 70 & 56 & \\
\hline \multirow[t]{6}{*}{ Minerals } & \multirow[t]{2}{*}{$\mathrm{Ca}(\mathrm{mg} / 100 \mathrm{~g})$} & $\mathrm{Y}$ & 304 & 460 & 254 & \\
\hline & & $\mathrm{M}$ & 844 & 274 & 607 & \\
\hline & \multirow[t]{2}{*}{$\mathrm{K}(\mathrm{mg} / 100 \mathrm{~g})$} & $\mathrm{Y}$ & 102 & 87.3 & 94.2 & \\
\hline & & $\mathrm{M}$ & 124 & 350 & 330 & \\
\hline & \multirow[t]{2}{*}{$\mathrm{P}(\mathrm{mg} / 100 \mathrm{~g})$} & $\mathrm{Y}$ & 92 & 11.7 & 42.8 & \\
\hline & & $M$ & 420 & 947 & 253 & \\
\hline
\end{tabular}

Key: (Y): Young and (M): Matured.

Results in Figure 2 indicate that, the percentage crude fibre is higher than the cellulose and proteins for all species, except Panicum coensis. The higher values of proteins, vitamins and carbohydrates in wet season and young plants are attributed to active synthesis of the materials resulting from active synthesis of cell materials required for growth and development of the plants associated with good conditions offered by the wet season (Plank 1990). As an adaptation to counteract harsh environment or weather, plants are capable of utilizing the favourable conditions to produce cell materials that are stored for growth and utilization during harsh conditions at the old stage of development, when active synthesis is replaced by active degeneration of the cell materials (Plank 1990). Similarly, the nutritional quality of herbaceous plants is influenced by climate (Arzani et al. 2008), soil nutrient status (Tessema et al. 2011), grazing regime (Henkin et al. 2011) and management aspects (Van der Westhuizen et al. 2005). Therefore, the findings of this study corresponded to this natural adaptation by plants and management practices performed at the Island.
Thus, the more matured species, the lower values of proteins and vitamins, as the decrease is associated with senescence stages of plants as most of the cells and tissues start to degenerate with age (Plank 1990). Comparison between young and matured fronds for Hyparrhennia filipendula, Eragrostis cilianensis and Digitaria velutina showed a decreasing trend from young to matured plants in terms of proteins, crude fibres (except for $E$. cilianensis) and vitamins $\mathrm{A}$ and $\mathrm{C}$, and a reversing trend in minerals like $\mathrm{Ca}$ (except for E. cilianensis), $\mathrm{K}$ and $\mathrm{P}$ (Table 3), which is consistent with what Mahala et al. 2009 observed in natural pasture. Mahala et al. (2009) argued that the nutritive values of herbaceous forages are affected by age or development stage and individual plant species. The variations in terms of forage quality available at grazers' disposal provide different diet requirements to the animals. Nonetheless, most of the grazers prefer short grasses that are at their youth stage of development due to accessibility factor, thus providing them with rich nutritional values contained in a plant.

In terms of individual species, results in Figure 2 indicate that $H$. filipendula, $E$. 
cilianensis, D. velutina and $C$. dactylon had higher crude fibres and carbohydrates contents, but had low protein contents compared to $P$. coensis, D. milanjiana and $E$. ciliaris. These three species ( $P$. coensis, $D$. milanjiana and $E$. ciliaris) had mean percentage protein contents above $10 \mathrm{mg} / 100$ g. As for vitamins, all grazed species in wet season had high vitamins $\mathrm{A}$ and $\mathrm{C}$; with three species $H$. filipendula, E. cilianensis and $D$. velutina registering less than $0.5 \mathrm{mg} / \mathrm{g}$ (Figure 2).

As for vitamin $\mathrm{A}$ and $\mathrm{C}$, results in Figure 3 indicate that all the selected grazed plant species samples had higher vitamin $\mathrm{C}$ than vitamin A except $C$. dactylon and $P$. coensis. Plant species E. cilianensis D. milanjiana and $C$. dactylon had the highest contents of vitamins $\mathrm{A}$ and $\mathrm{C}$ with their mean values for vitamins above $120 \mathrm{mg} / 100 \mathrm{~g}$. Of the seven selected grazed plant species $C$. dactylon, $E$. ciliaris and $P$. coensis recorded higher vitamin A than the rest with their mean vitamin dwindling between $80 \mathrm{mg} / 100 \mathrm{~g}$ to $125 \mathrm{mg} / 100$ g. Hyparrhennia filipendula recorded the lowest crude protein contents followed by Eragrostis cilianensis and Digitaria velutina (Figure 3).

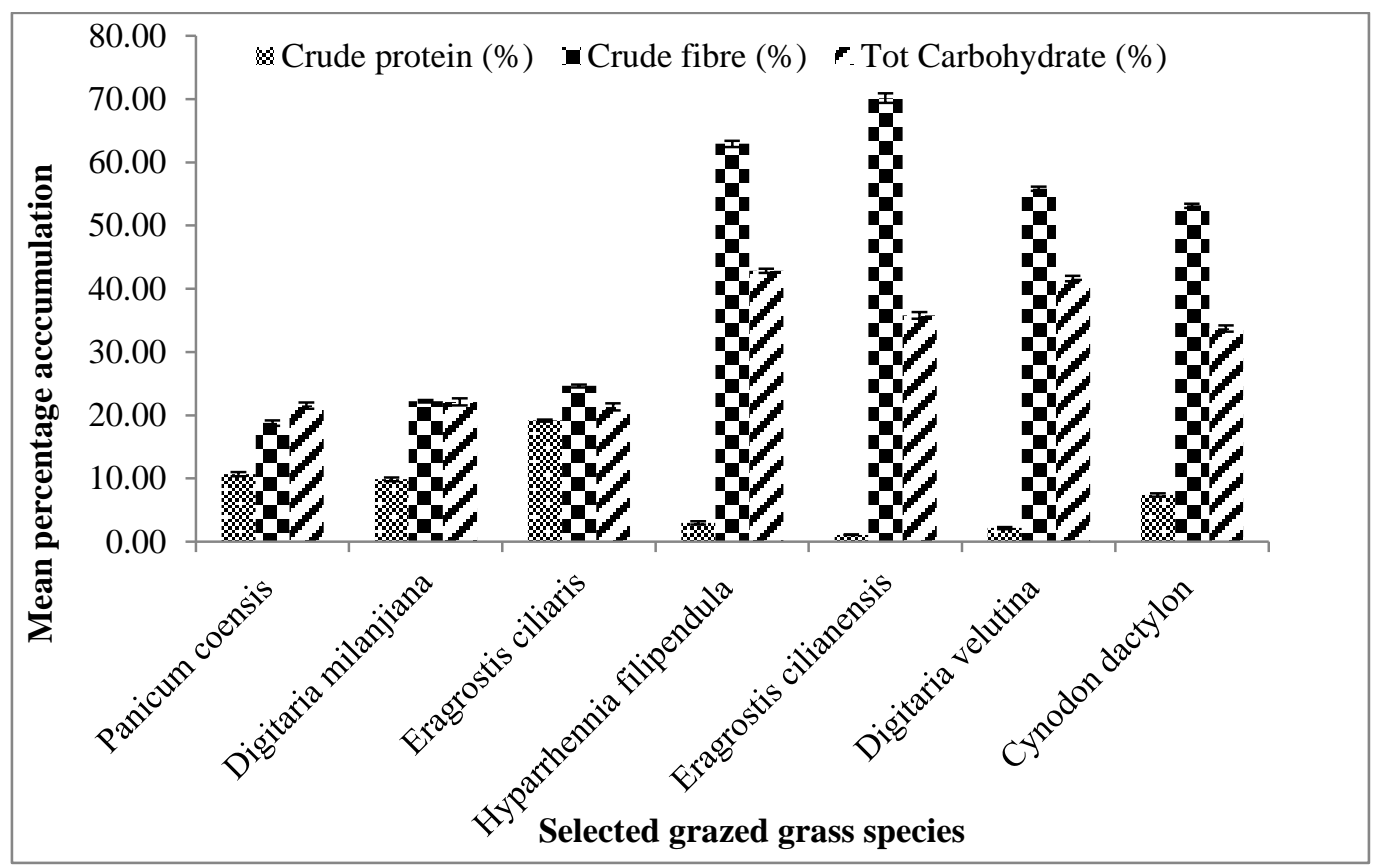

Figure 2: Variations in protein, crude fibre and carbohydrates contents on selected grazed species in Saanane Island. 


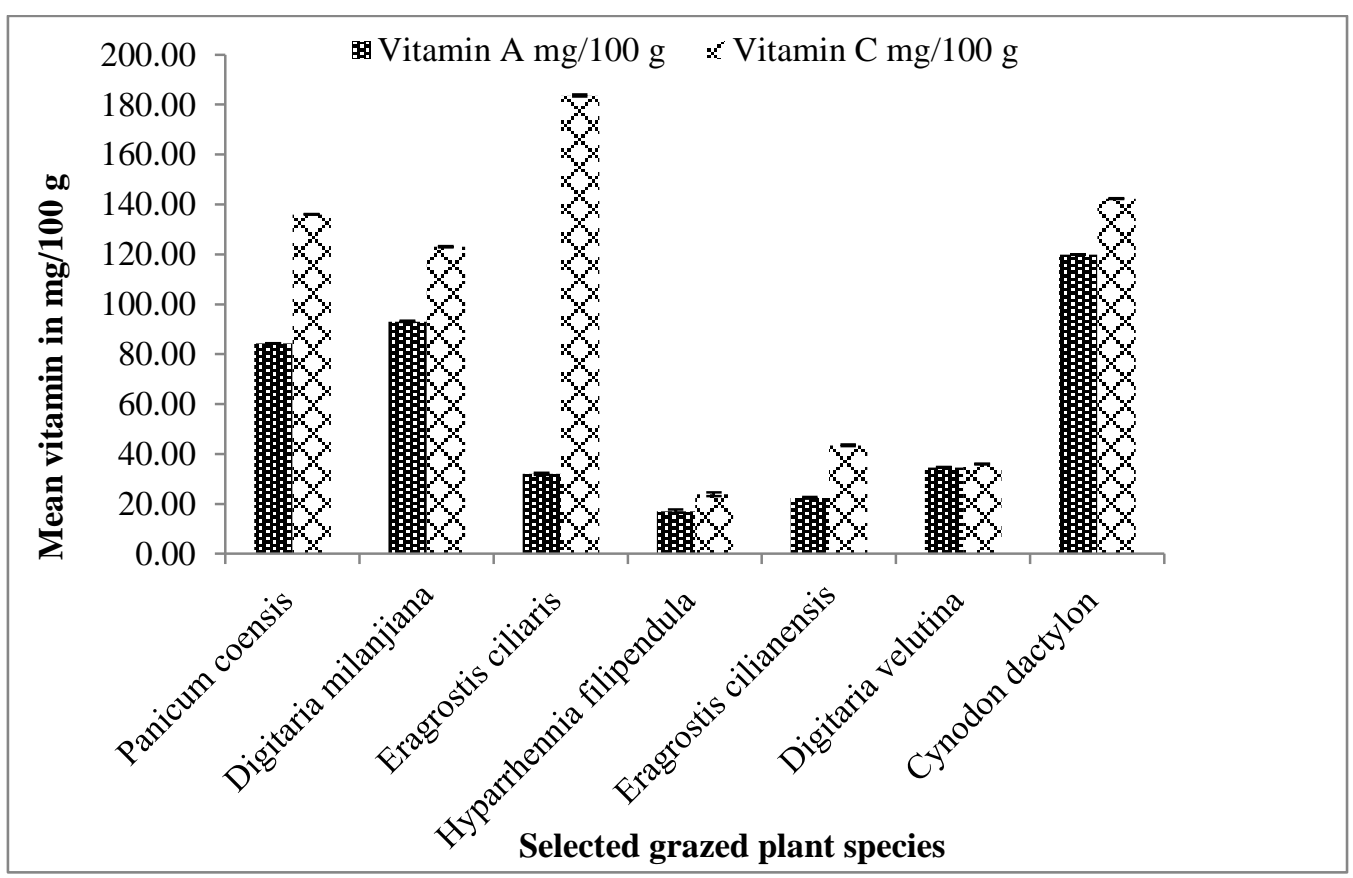

Figure 3: Variations in vitamins A and C contents on selected grazed species in Saanane Island.

\section{Seasonal variations in forage quality}

The results in Tables 2 and 3 indicate seasonal variations in forage quality among seven selected grazed grass species with wet season samples having higher values for proteins and carbohydrates except E. ciliaris. These findings are consistent with Bayble et al. (2007) findings who reported that the mineral contents of herbaceous forages decline as the stage of maturity advances. In terms of vitamin $\mathrm{A}$, vitamin $\mathrm{C}$ and crude fibres, all wet season samples recorded lower values than dry season samples (Table 2) except $C$. dactylon and $P$. coensis; $E$. cilianensis and E. ciliaris for vitamin A, vitamin $\mathrm{C}$ and crude fibre, respectively. A similar trend was observed in minerals where the dry season samples had higher values compared to the wet season samples (Table 3).

Clear trends of variations were observed in concentrations of $\mathrm{K}, \mathrm{Na}, \mathrm{Ca}, \mathrm{Fe}$, and $\mathrm{P}$ between the wet season and dry seasonal samples of the seven selected grazed species (Table 2 and Table 3). The results indicate that the wet season samples were higher for $\mathrm{K}, \mathrm{Ca}$ and $\mathrm{P}$ concentrations for seven selected grazed species except for Cynodon dyctylon.
Nonetheless, there were great variations among the species forming the seven selected grazed species in terms of their mineral concentrations. The differences in amounts of minerals accumulated are attributed to species ability to accumulate and store minerals relative to species utilization. As for $\mathrm{Na}$ and $\mathrm{Fe}$, the concentrations in wet season samples were lower than in dry season samples because plant species tend to accumulate high levels of $\mathrm{Na}$ when the external salinity is high. Dry season is associated with increased external salinity levels, thus plant species are likely to accumulate large amounts of $\mathrm{Na}$ compared to wet season (Khan et al. 2000, Ramos et al. 2004).

Statistical comparison using unpaired $\mathrm{t}$ test found extremely significant differences ( $\mathrm{P}$ $<0.0001 ; \mathrm{DF}=6$ ) in values for $\mathrm{Fe}, \mathrm{Ca}, \mathrm{K}$, and $\mathrm{P}$ concentrations as well as for vitamin $\mathrm{A}$, crude proteins, carbohydrates and crude fibres for Cynodon dactylon species between the wet season and dry season samples except for vitamin C (Table 4). Cynodon dactylon was chosen to represent other species to reflect variations in minerals and nutritional contents between wet and dry season since it is the most grazed species found on the study site. 
The minerals and vitamins content of plants vary not only among its various plant parts, but also changes with age and stage of development. There are also varieties differences which will affect the mineral and vitamin contents found in various plant parts, environmental conditions and management practices among other factors. A plant analysis interpretation is based on a comparison of the nutrient concentrations found in a particular plant part taken at a specific time by grazers or browsers. Vitamins, proteins, carbohydrates and other mineral contents availability to grazers/browsers are governed by animal biological control mechanisms and the diet requirements of the animal (Fennema 1996). Thus, for complete description of the nutritional adequacy of the grazer/browser, three factors according to Fennema (1996) are important: the concentrations of vitamins, proteins, carbohydrates and other minerals available at the time of consumption, identity of various chemical species in the vitamins and bioavailability of those forms of vitamins, proteins, carbohydrates and other minerals as they exist in the grazed and browsed materials.

The increase in the vitamin A, vitamin C, fibres and minerals is attributed to lignification and calcification processes associated with plant maturity (Teka et al. 2012). Also the increase is linked with accumulation of $\mathrm{Ca}$ contents in the fibres in a form of crystals of calcium oxalate in the leaves associated with maturation and hardening of the stem and leaves as the plant ages; this observation is consistent with the findings of Plank (1990) and Teka et al. (2012) who observed that the Ca levels in plants tend to increase with the age of the plant.

Comparing grazed species and browsed species in terms of mineral concentrations (mg/100 g) for dry season samples, the results indicate that browsed species had higher concentrations of $\mathrm{K}, \mathrm{Na}, \mathrm{Ca}, \mathrm{Fe}$ and $\mathrm{P}$ than all the seven selected grazed species. While $\mathrm{Ca}$ concentrations remained relatively unchanged between the browsed and grazed species. Similarly, comparing crude proteins, crude fibres and total carbohydrates between selected grazed and browsed species, great variations existed among the species and between the two categories. Results in Figure 4 showed that selected grazed species had higher percentage crude fibres than selected browsed species. The mean percentage crude fibres for all selected grazed species ranged between $60 \%$ and $80 \%$ (Figure $4 a$ ), while that of selected browsed species fluctuated between $30 \%$ and $45 \%$ crude fibres except Commiphora africana which had percentage crude fibres values similar to selected grazed species (Figure 4b). For crude proteins and carbohydrates, the levels are similar for selected grazed species and browsed species as the percentage values ranged between $10 \%$ and $22 \%$ (Figure $4 \mathrm{a} \& 4 \mathrm{~b}$ ).

It is clear that higher levels of fibres for grazed species relative to protein and carbohydrate contents are associated with maturity of the plant during dry season, protein and carbohydrate levels would be higher during wet season when the plant is actively synthesizing cells for growth and production of flowers and fruits. As for selected browsed species, the variations are not clearly related to maturity of the plant but rather reallocation of resources for onset of new leaves, flowers and fruits. Examining Figure $4 \mathrm{~b}$ for browsed materials in the same dry season, the percentages proteins and carbohydrates were still maintained at lower levels than the percentage crude fibre whose percentage values fluctuated between 10 and $15 \%$. It is clear that there is increase in percentage fibre contents and a clear decrease in percentage protein and carbohydrate contents as one moves across the species from E. ciliaris to D. velutina as indicated in Figure 4a. 
Table 2: Concentrations of vitamin A, vitamin C, crude proteins, crude fibres and total cellulose in grazed materials in wet and dry seasons

\begin{tabular}{|c|c|c|c|c|c|c|c|c|}
\hline Species name & $\begin{array}{l}\text { Sample } \\
\text { size }\end{array}$ & Season & $\begin{array}{ll}\text { Vitamin } & A \\
\text { mg/100 g } & \end{array}$ & $\begin{array}{l}\text { Vitamin } \\
\mathrm{mg} / 100 \mathrm{~g}\end{array}$ & $\mathbf{C}$ & $\begin{array}{l}\text { Crude protein } \\
\mathrm{mg} / 100 \mathrm{~g}\end{array}$ & $\begin{array}{l}\text { Crude } \\
\text { mg/100 g }\end{array}$ & $\begin{array}{l}\text { Total cellulose } \\
\mathrm{mg} / 100 \mathrm{~g}\end{array}$ \\
\hline Panicum coensis & 4 & Dry & $55.13 \pm 0.08$ & $160.64 \pm 0.65$ & & $10.47 \pm 0.34$ & $55.55 \pm 0.15$ & $7.19 \pm 0.11$ \\
\hline \multirow[t]{2}{*}{ Digitaria milanjiana } & 4 & Wet & $92.60 \pm 1.30$ & $123.08 \pm 0.52$ & & $11.52 \pm 0.74$ & 22.200 .50 & $21.82 \pm 1.57$ \\
\hline & 4 & Dry & $110.23 \pm 0.05$ & $171.39 \pm 0.33$ & & $9.84 \pm 0.38$ & $54.28 \pm 0.29$ & $7.96 \pm 0.36$ \\
\hline Eragrostis ciliaris & 4 & Wet & $32.02 \pm 0.20$ & $183.64 \pm 0.98$ & & $20.53 \pm 0.38$ & $24.60 \pm 0.58$ & $21.89 \pm 1.63$ \\
\hline \multirow[t]{2}{*}{ Hyparrhennia filipendula } & 4 & Wet & $16.93 \pm 0.88$ & $23.90 \pm 2.5$ & & $8.33 \pm 0.68$ & $63.07 \pm 1.20$ & $42.71 \pm 0.90$ \\
\hline & 4 & Dry & 65.900 .14 & $109.67 \pm 4.73$ & & $2.98 \pm 0.34$ & $78.75 \pm 0.39$ & $10.62 \pm 0.55$ \\
\hline \multirow[t]{2}{*}{ Eragrostis cilianensis } & 4 & Wet & $22.43 \pm 0.28$ & $43.42 \pm 0.79$ & & $19.76 \pm 0.18$ & $70.01 \pm 1.70$ & $35.33 \pm 1.20$ \\
\hline & 4 & Dry & $126.59 \pm 0.15$ & $110.52 \pm 0.21$ & & $1.02 \pm 0.33$ & $68.85 \pm 0.76$ & $21.96 \pm 0.91$ \\
\hline Cynodon dactylon & 4 & Dry & $97.61 \pm 0.34$ & $416.48 \pm 3.46$ & & $7.18 \pm 0.44$ & $74.10 \pm 0.35$ & $20.65 \pm 0.26$ \\
\hline
\end{tabular}

Total number of samples 28

The values are presented as mean \pm standard error of the mean (SEM). 
Table 3: Concentrations of the minerals ( $\mathrm{Fe}, \mathrm{Ca}, \mathrm{Na}, \mathrm{K}$ and $\mathrm{P}$ ) in grazed materials in wet and dry seasons

\begin{tabular}{|c|c|c|c|c|c|c|c|}
\hline Species name & $\begin{array}{l}\text { Sample } \\
\text { size }\end{array}$ & Season & $\begin{array}{l}\mathrm{K} \\
(\mathrm{mg} / \mathbf{1 0 0} \mathrm{g})\end{array}$ & $\begin{array}{l}\mathrm{Na} \\
(\mathrm{mg} / 100 \mathrm{~g})\end{array}$ & $\begin{array}{l}\mathrm{Ca} \\
(\mathrm{mg} / \mathbf{1 0 0} \mathrm{g})\end{array}$ & $\begin{array}{l}\mathrm{Fe} \\
(\mathrm{mg} / 100 \mathrm{~g})\end{array}$ & $\begin{array}{l}P \\
(\mathrm{mg} / \mathbf{1 0 0} \mathrm{g})\end{array}$ \\
\hline \multirow[t]{2}{*}{ Panicum coensis } & 4 & Wet & $319.67 \pm 0.87$ & $5.95 \pm 0.10$ & $763.91 \pm 0.36$ & $27.03 \pm 0.16$ & $267.27 \pm 0.06$ \\
\hline & 4 & Dry & $217.14 \pm 0.39$ & $42.89 \pm 0.23$ & $136.44 \pm 0.92$ & $124.7 \pm 0.10$ & $198.53 \pm 0.44$ \\
\hline \multirow[t]{2}{*}{ Digitaria milanjiana } & 4 & Wet & $346.69 \pm 2.04$ & $2.18 \pm 0.31$ & $669.59 \pm 0.61$ & $17.71 \pm 0.20$ & $300.96 \pm 0.12$ \\
\hline & 4 & Dry & $111.02 \pm 0.85$ & $24.73 \pm 4.01$ & $145.44 \pm 0.68$ & $77.05 \pm 0.13$ & $187.46 \pm 0.14$ \\
\hline \multirow[t]{2}{*}{ Eragrostis ciliaris } & 4 & Wet & $347.31 \pm 2.31$ & $7.08 \pm 0.18$ & $273.49 \pm 0.50$ & $17.41 \pm 0.27$ & $947.21 \pm 0.09$ \\
\hline & 4 & Dry & $164.92 \pm 0.86$ & $25.04 \pm 0.21$ & $153.12 \pm 0.55$ & $135.99 \pm 0.22$ & $388.38 \pm 0.39$ \\
\hline \multirow[t]{2}{*}{ Hyparrhennia filipendula } & 4 & Wet & $124.46 \pm 0.53$ & $2.84 \pm 0.38$ & $844.19 \pm 0.50$ & $7.22 \pm 0.12$ & $420.00 \pm 0.22$ \\
\hline & 4 & Dry & $104.55 \pm 2.13$ & $39.22 \pm 0.46$ & $304.40 \pm 0.57$ & $52.63 \pm 0.09$ & $92.12 \pm 0.18$ \\
\hline \multirow[t]{2}{*}{ Eragrostis cilianensis } & 4 & Wet & $447.5 \pm 2.42$ & $4.13 \pm 0.09$ & $469.84 \pm 1.04$ & $11.96 \pm 0.17$ & $979.93 \pm 0.22$ \\
\hline & 4 & Dry & $86.26 \pm 1.07$ & $31.45 \pm 0.64$ & $459.95 \pm 0.82$ & $30.04 \pm 0.16$ & $11.66 \pm 0.07$ \\
\hline \multirow[t]{2}{*}{ Digitaria velutina } & 4 & Wet & $329.63 \pm 0.84$ & $2.10 \pm 0.13$ & $606.27 \pm 0.80$ & $12.88 \pm 0.19$ & $253.04 \pm 0.11$ \\
\hline & 4 & Dry & $93.61 \pm 1.03$ & $17.32 \pm 0.47$ & $253.8 \pm 0.42$ & $37.03 \pm 0.13$ & $42.90 \pm 0.11$ \\
\hline \multirow[t]{2}{*}{ Cynodon dactylon } & 4 & Wet & $222.58 \pm 2.03$ & $5.00 \pm 0.11$ & $491.73 \pm 0.48$ & $11.89 \pm 0.17$ & $975.99 \pm 0.13$ \\
\hline & 4 & Dry & $313.26 \pm 0.74$ & $23.91 \pm 0.32$ & $186.82 \pm 0.49$ & $135.01 \pm 0.18$ & $218.16 \pm 0.09$ \\
\hline
\end{tabular}


Table 4: Statistical summary for unpaired t-test between wet and dry season samples for Cynodon dactylon

\begin{tabular}{lllll}
\hline Parameters & t- value & P- values & Degrees of freedom & Remarks \\
\hline $\mathrm{Fe}$ & 873.67 & 0.0001 & 6 & Very significant \\
$\mathrm{Ca}$ & 124.61 & 0.0001 & 6 & Very significant \\
$\mathrm{Na}$ & 70.68 & 0.0001 & 6 & Very significant \\
$\mathrm{K}$ & 4.49 & 0.0041 & 6 & Very significant \\
$\mathrm{P}$ & 1289.90 & 0.0001 & 6 & Very significant \\
Vitamin A & 33.39 & 0.0001 & 6 & Very significant \\
Vitamin C & 1.064 & 0.3280 & 6 & Not significant \\
Crude protein & 36.69 & 0.0001 & 6 & Very significant \\
Total carbohydrates & 54.94 & 0.0001 & 6 & Very significant \\
Crude fibres & 59.18 & 0.0001 & 6 & Very significant \\
\hline
\end{tabular}

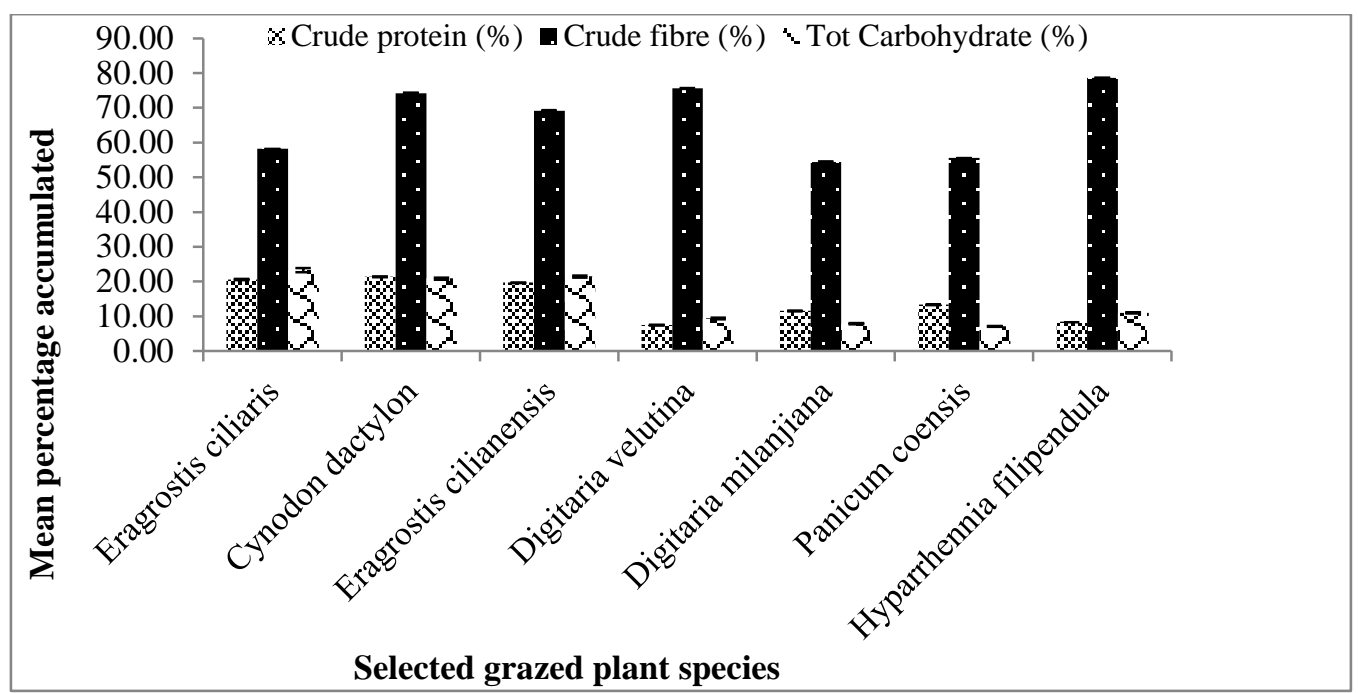

Figure 4a: Crude protein, fibres and carbohydrates for selected grazed species in dry season.

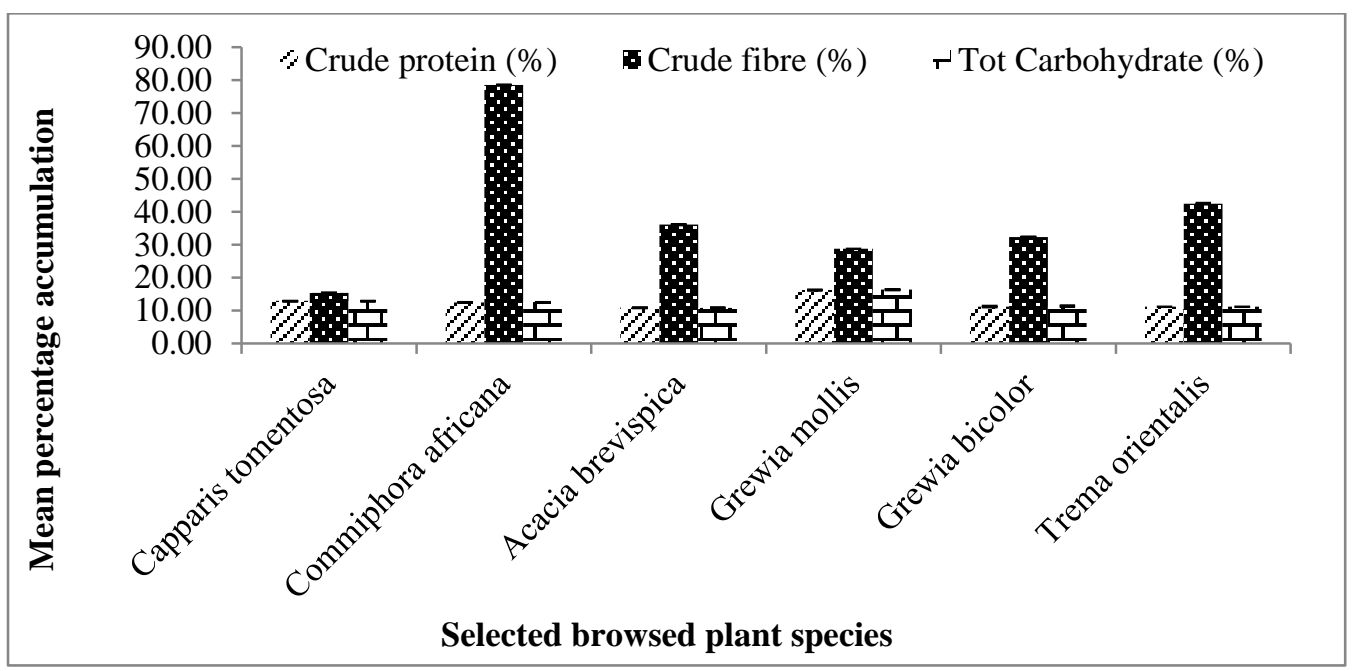

Figure 4b: Crude proteins, fibres and carbohydrates for selected browsed species dry season. Error bars are presented as SEM. 
In terms of vitamins, selected browsed species had higher vitamin contents compared to selected grazed species. Results in Figure $5 \mathrm{~b}$ indicate that all selected browsed species had their vitamin values above $100 \mathrm{mg} / 100 \mathrm{~g}$, while those for selected grazed species the values for vitamins were below $100 \mathrm{mg} / 100 \mathrm{~g}$ except Cynodon dactylon which recorded a value of $120 \mathrm{mg} / 100 \mathrm{~g}$ (5a). Comparing vitamins $\mathrm{A}$ and $\mathrm{C}$ between selected grazed and selected browsed plant species for dry season samples (Figure 5a \& b), it was indicated that vitamin $\mathrm{C}$ for all analysed samples were higher than vitamin A for both grazed and browsed species except Trema orientalis (Figure 5a and Figure 5b). For selected browsed species a clear trend of high vitamin $\mathrm{C}$ is observed for three species Capparis tomentosa, Commiphora africana and Acacia brevispica except Trema orientalis which exerted completely reversed trend where vitamin A was higher than vitamin $\mathrm{C}$ (Figure $5 b)$. This trend is likely to be attributed to tendency of decreasing values of proteins and vitamins associated with senescence stages of plants as most of the cells and tissues start to degenerate with age (Plank 1990).

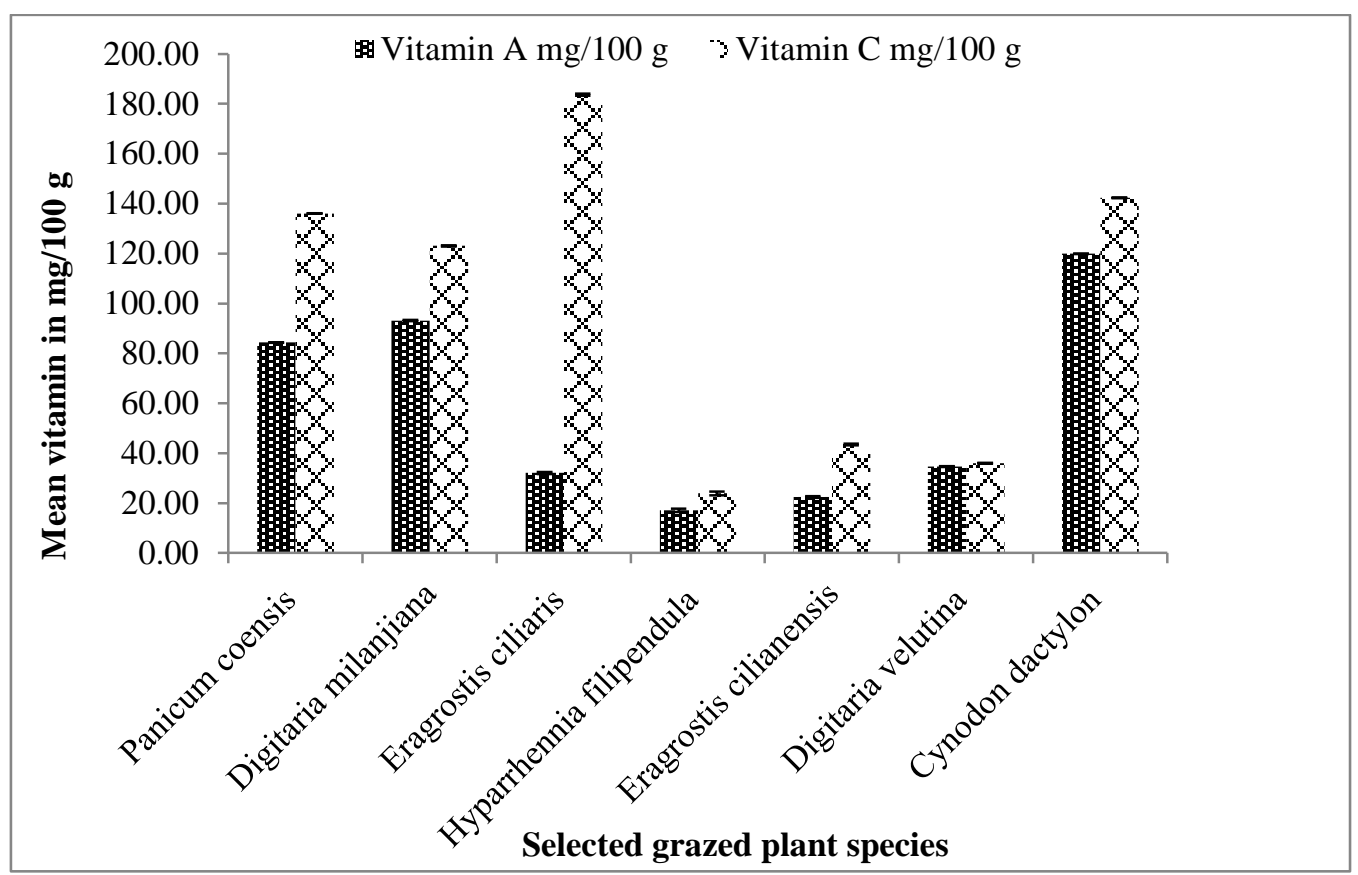

Figure 5a: Variations in vitamins $\mathrm{A}$ and $\mathrm{C}$ for selected grazed plant species in dry season. Error bars are presented as SEM. 


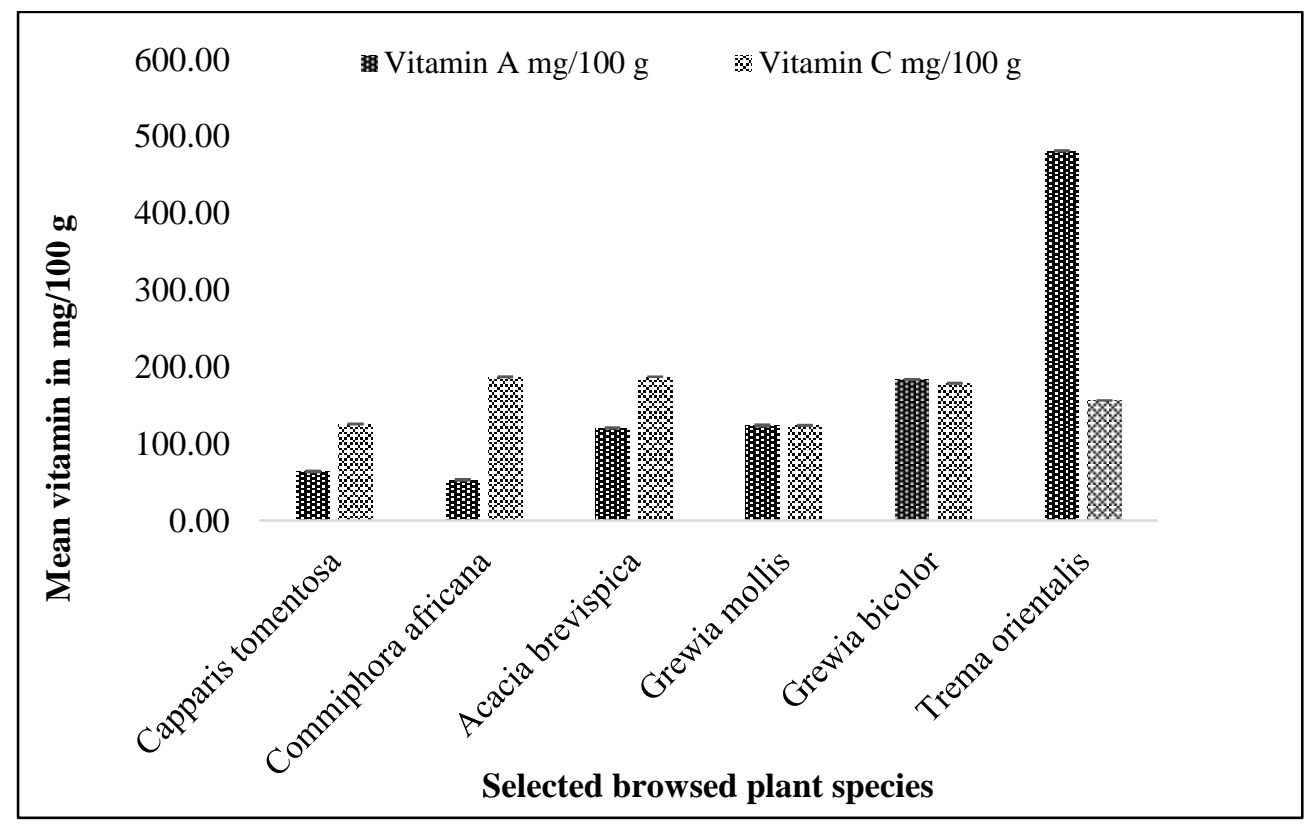

Figure 5b: Variations in vitamins $\mathrm{A}$ and $\mathrm{C}$ for browsed species in dry season. Error bars are presented as SEM.

\section{Conclusion and recommendations}

Important ingredients such as crude proteins, vitamins and minerals are important components of the forage materials. Low protein and carbohydrate contents will mean forage with low energy values for the animals while vitamins and minerals are required for the regulation of the body's metabolic functions. Deficiency in the above nutritional requirements would lead to animal's poor health, disease condition and even death. Usually animals tend to avoid unpalatable forage with high fibre contents and low in proteins and minerals. Assessment in rangelands usually finds unpalatable forage remaining intact or slightly browsed. Herbivores could be browsers or grazers or omnivores. In places where grasses and sedges are predominant, more grazers could be supported; and in areas where forbs and woody vegetation predominate, browsers will be more supported. Most habitats however, tend to have both forage materials, though at varying proportions and quality.

\section{References}

Allen SE 1989 Chemical Analysis of Ecological Materials. 2nd edition, Blackwell Scientific Publications, Oxford.

AOAC 2002 Official Methods of Analysis of the Official Analytical Chemists, $17^{\text {th }}$ ed. (Horwitz W ed), Association of Official Analytical Chemists, Washington DC.

Arzani H, Sadeghimanesh MR, Azarniv H, Asadian GH and Shahriyari E 2008 Study of phonological stages effect values of twelve species in Hamadan rangelands. Iran. J. Range Desert Res. 15: 42-50.

Bayble T, Melaku S and Prasad NK 2007 Effects of cutting dates on nutritive value of Napier (Pennisetum purpureum) grass planted sole and in association with Desmodium (Desmodium intortum) or Lablab (Lablab purpureus). Livestock Res. Rural Dev. 19: 120-136.

Beentje HJ1994 Kenya Trees, Shrubs and Lianas. National Museum of Kenya, Nairobi.

Fennema OR 1996 Food Chemistry Fourth Edition; CRC Press. Taylor and Francis Group. Boka, Raton London New York. 
FTEA 2002 Flora of Tropical East Africa Book by Diane Mary Bridson.

Ganskopp D and Bohnert D 2001 Nutritional dynamics of 7 northern Great basin grasses. J. Rangeland Ecol. Manag. 54: 640-647.

Greenway PJ 1973 A classification of the vegetation of East Africa. Kirkia 9: 1-68.

Henkin N, Ungar ED, Dvash L, Perevolotsky A, Yehuda Y, Sternbergs M, Voet H and Landau SY 2011 Effects of cattle grazing on herbage quality in a herbaceous Mediterranean rangeland. Grass Forage Sci. 66: 516-525.

Katalihwa M 1981 Wild animals in captivity in Tanzania: with special reference to Saa Nane Island Zoo. MSc thesis, University of Dar es Salaam.

Khan MA, Ungar IA, Showalter AM 2000 Effects of salinity on growth, water relations and ions accumulation of the subtropical perennial halophyte, Atriplex griffithii var.stockii. Ann. Bot. 85: 225232.

Krupa S, Muntifering R, Chappelka A 2004 Effect of ozone on plant nutritive quality characteristics for ruminant animals. The Botanica 54: 1-12.

Mahala AG, Nsahlai IV, Basha NAD and Mohammed LA 2009 Nutritive evaluation of natural pasture at early and late rainfall season in Kordofan and Butana, Sudan, Aust J. Basic Appl. Sci. 3: 4327-4332.

Plank CO 1990 Plant Analysis HandBook for Georgia. University of Georgia, college of Agriculture and Environmental Sciences Laboratories.

Ramos J, López MJ, Benlloch, M 2004 Effect of $\mathrm{NaCl}$ and $\mathrm{KCl}$ salts on the growth and solute accumulation of the halophyte Atriplex nummularia. Plant Soil 259: 163168.

Shio K 1996 Phosphorus. In: Sparks DL (Ed). Method of Soil Analysis: Chemical Methods. Part 3, pp. 869-921. SSSA, Madison, WI.

Teka HI, Madakadze C, Angassa A, Hassen A 2012 Effect of seasonal variation on the nutritional quality of key herbaceous species in semi-arid areas of Borana, Ethiopia. Indian J. Animal Nutr. 29(4): 324-332.

Tessema ZK, de Boer WF, Baars RMT and Prins HHT 2011 Changes in soil nutrients, vegetation structure and herbaceous biomass in response to grazing in a semiarid savanna of Ethiopia. J. Arid Environ. 75: 662- 670.

Van der Westhuizen HC, Snyman HA and Fouchè HJ 2005 A degradation gradient for the assessment of rangeland condition of a semi-arid sourveld in southern Africa. Afr. J. Range Forage Sci. 22: 47-58.

Walker BH 1970 An evaluation of eight methods of botanical analysis on grasslands in Rhodesia. J. Appl. Ecol. 7: 403-416.

White F 1983 The vegetation of Africa. The descriptive memoir to accompany the UNESCO/ AETFAT/UNSO vegetation map of Africa. UNESCO, Paris France.

Zar JH 1999 Biostatistical Analysis. $2{ }^{\text {nd }}$ Ed. Prentice International Inc.

Zohary M 1973 Geobotanical foundations of the Middle East. Gustav Fisher Verlag, Stuttgart. 